\title{
ИСТОЧНИКОВЕДЕНИЕ
}

УДК / UDC 94(47).084.8

DOI: $10.22162 / 2500-1523-2021-4-744-763$

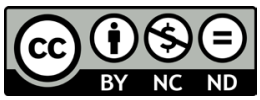

\section{Исчезающая история «13 лет и 13 дней»: проблемы поиска и сохранения архивных материалов о калмыках на спецпоселении в Сибири. Часть 1}

\section{Виктория Васильевна Куканова ${ }^{1}$, Уташ Борисович Очиров $^{2}$}

${ }^{1}$ Калмыцкий научный центр РАН (д. 8, ул. им. И. К. Илишкина, 358000 Элиста, Российская Федерация)

кандидат филологических наук, директор

iD 0000-0002-7696-4151.E-mail: vika.kukanova@gmail.com

${ }^{2}$ Калмыцкий научный центр РАН (д. 8, ул. им. И. К. Илишкина, 358000 Элиста, Российская Федерация) доктор исторических наук, доцент, главный научный сотрудник

(iD) 0000-0001-9957-5215. E-mail: utash-ochirov@yandex.ru

(C) КалмНЦ РАН, 2021

(C) Куканова В. В., Очиров У. Б., 2021

Аннотация. Введение. Статья была написана на основе доклада, зачитанного на XIII Bceроссийском съезде востоковедов. В ней рассматриваются проблемы поиска материалов о калмыках, проживавших на спецпоселении в Сибирь в 1944-1957 гг., и необходимость их сохранения и дублирования для исследователей-калмыковедов. Maтериаль u методы. При написании статьи был использован широкий спектр научных методов, как общенаучных (анализ, синтез и др.), так и специально-исторических (историко-генетический, историко-системный и др.). Необходимость сравнения условий хранения и доступа к фондам архивов разных регионов и разной ведомственной принадлежности обусловило активное применение историко-сравнительного метода. Результаты. Статья посвящена жизни калмыцкого народа на спецпоселении в сибирских регионах в период между 28 декабря 1943 г. и 9 января 1957 г. В ходе этих «13 лет и 13 дней», которые для калмыков фактически уже стали устойчивой фольклорной формулой для обозначения сибирской ссылки, калмыцкий народ перенес огромные лишения и невзгоды, потерял почти треть своей численности. В первой части статьи приведено краткое описание процесса депортации калмыцкого народа в ходе операции «Улусы» и иных выселений. В статье подчеркивается, что причины депортации калмыцкого народа, приведенные в официальном постановлении Президиума Верховного совета СССР, не соответствуют действительности и носят огульный характер. В работе описывается география расселения калмыков-спецпереселенцев, условия их жизни на спецпоселении. Авторы обращают внимание на наиболее характерные проблемы, с которыми пришлось столкнуться калмыкам-спецпереселенцам. Особое внимание обращено на демографические потери калмыцкого народа в ходе депортации. Во второй части статьи будут рассмотрены проблемы поиска и сохранения архивных материалов о жизни калмыков на спецпоселении в Сибири в 1944-1957 гг. 
Ключевые слова: Калмыцкая АССР, калмыки, Великая Отечественная война 19411945 гг., сталинские репрессии; депортации народов, спецпоселение, Сибирь, архивы Благодарность. Исследование проведено в рамках государственной субсидии - проект «Комплексное исследование процессов общественно-политического и культурного развития народов Юга России» (номер госрегистрации: АААА-А19-119011490038-5). Для цитирования: Куканова В. В., Очиров У. Б. Исчезающая история «13 лет и 13 дней»: проблемы поиска и сохранения архивных материалов о калмыках на спецпоселении в Сибири. Часть 1 // Монголоведение. 2021. Т. 13. № 4. С. 744-763. DOI: 10.22162/25001523-2021-4-744-763

\title{
The Vanishing History of 'Thirteen Years and Thirteen Days': Problems of Searching and Preserving Archival Materials on Repressed Kalmyks in Siberia. Part 1
}

\author{
Viktoria V. Kukanova ${ }^{1}$, Utash B. Ochirov ${ }^{2}$ \\ ${ }^{1}$ Kalmyk Scientific Center of the RAS (8, Ilishkin St., 358000 Elista, Russian Federation) \\ Cand. Sc. (Philology), Director \\ iD 0000-0002-7696-4151. E-mail: vika.kukanova@gmail.com
${ }^{2}$ Kalmyk Scientific Center of the RAS (8, Ilishkin St., 358000 Elista, Russian Federation)
Dr. Sc. (History), Associate Professor, Chief Research Associate
(iD) 0000-0001-9957-5215. E-mail: utash-ochirov@yandex.ru

\author{
(C) KalmSC RAS, 2021 \\ (C) Kukanova V. V., Ochirov U. B., 2021
}

\begin{abstract}
Introduction. The article publishes a report delivered at the Thirteenth Congress of Orientalists and deals with problems of searching materials on repressed Kalmyks and their 1944-1957 life in Siberia with special emphasis be laid on their preservation and duplication for specialists in Kalmyk studies. Materials and methods. The study employs a wide range of research methods, both common scientific (analysis, synthesis, etc.) and special historical ones (historical genetics, historical systemic methods, etc.). The comparative historical methods proves instrumental in identifying actual storage and access conditions at archives across different regions, agencies, and authorities. Results. The paper covers the Siberian period of the repressed Kalmyk people's life between 28 December 1943 and 9 January 1957. The 'thirteen years and thirteen days' - to have become a somewhat fixed folklore formula - witnessed tremendous hardships and miseries experienced and survived by two thirds of the population only. Part 1 of the article reviews the deportation proper (Operation Ulusy and other similar forced relocations). Special attention is paid to that the causes proclaimed in the official decree by the Presidium of the USSR Supreme Council were completely groundless and had nothing to do with reality. The geography of Kalmyk Deportation, living conditions, and typical problems faced by repressed Kalmyks are also outlined. The work emphasizes demographic losses of the ethnos. Part 2 shall examine the problems of searching and preserving related archival materials on Siberian life of the Kalmyks in 1944-1957.
\end{abstract}

Keywords. Kalmyk ASSR, Kalmyks, Great Patriotic War of 1941-1945, Stalinist repressions, ethnic deportations, forced settlements, Siberia, archives

Acknowledgements. The reported study was funded by government subsidy, project no. AAAA-A19-119011490038-5 'Sociopolitical and Cultural Development of South Russia's Peoples: Comprehensive Studies of Respective Processes'. 


\section{Монголоведение • Mongolian Studies • $2021 \bullet$ T. 13 • № 4}

For citation: Kukanova V. V., Ochirov U. B. The Vanishing History of 'Thirteen Years and Thirteen Days': Problems of Searching and Preserving Archival Materials on Repressed Kalmyks in Siberia. Part 1. Mongolian Studies (Elista). 2021; 13(4): 744-763. (In Russ.). DOI: $10.22162 / 2500-1523-2021-4-744-763$

\section{Введение}

Данная статья была написана на базе доклада, прочитанного и обсужденного на пленарном заседании XIII Всероссийского съезда востоковедов «Восточные архивы и архивоведение в современном мире: проблемы и перспективы» (Элиста, 5-8 октября 2021 г.). В этом докладе рассматривались проблемы поиска материалов о жизнедеятельности калмыков, высланных на спецпоселение в Сибирь в 1944-1957 гг., в региональных архивах и доказывалась необходимость их сохранения и дублирования для исследователей-калмыковедов.

\section{Обзор литературы}

В советские годы исследования о жизни калмыков на спецпоселении не поощрялись и даже если проводились, то весьма однобоко. Например, в обобщающей работе по истории Калмыкии ничего не писалось об операции «Улусы» и вызвавших ее причинах, об условиях жизни при первоначальном расселении, огромных демографических потерях калмыков. В тексте лишь говорилось, что было «сфабриковано ложное обвинение калмыцкого народа в сотрудничестве с гитлеровцами и предательстве интересов Родины» [Очерки 1970: 309]. Утверждалось, что «калмыки, несмотря на тяжелую моральную травму и большие лишения, на новых местах быстро осваивались... Местное население тепло встречало калмыков, оказывая посильную помощь в пище, жилье и устройстве...» [Очерки 1970: 317]. Весь остальной текст этого параграфа из главы VIII был посвящен трудовым подвигам калмыков на спецпоселении и награждениям некоторых из них [Очерки 1970: 317-333].

На завершающем этапе перестройки и в постсоветский период ситуация кардинально изменилась: исчез диктат идеологии над наукой, был открыт доступ к засекреченным ранее архивам, стали публиковаться воспоминания переживших депортацию. В 1989 г. была создана Комиссия по определению потерь населения Отделения истории АН СССР под руководством Ю. А. Полякова, которая в числе первых начала работу в Центральном государственном архиве Октябрьской революции (ныне этот архив входит в состав Государственный архив Российской Федерации) с ранее недоступной для историков статистической документацией органов госбезопасности и высших органов власти. В составе этой комиссии работал широко известный ныне историк-демограф В. Н. Земсков, который опубликовал большое количество трудов по статистике репрессированных, в том числе и спецпоселенцев [Земсков 1990; Земсков 1991a; Земсков 1991б; и др.]. В 2005 г. он защитил докторскую диссертацию по теме спецпоселенцев [Земсков 2005]. В своих работах В. Н. Земсков привел огромный объем сведений о количестве спецпоселенцев (в том числе калмыков) в разные годы. В те же годы свои исследования по истории насильственных переселений народов в период сталинизма начал Н. Ф. Бугай [Бугай 1989; Бугай 1991а; Бугай 1991б; Бугай 1992а; Бугай 1992б; Бугай 1995; и др.]. В своих работах ученый, который в 1993 г. возглавил департамент по делам депортированных и репрес- 


\section{Источниковедение}

сированных народов Министерства по делам федерации и национальностей РФ, описал общую картину депортаций народов, ввел в оборот большое количество документов по данной теме, выдвинул первые научные концепции в этой области. Одна из его работ была посвящена непосредственно высылке калмыцкого народа и его жизни на спецпоселении [Бугай 1991б]. Свой вклад в изучение демографии спецпоселенцев внес демограф П. М. Полян [Полян 2001]. Помимо исследовательских работ, было опубликовано большое количество документов в различных сборниках [Депортации 1992; Иосиф Сталин 1992; История сталинского Гулага 2004; Сталинские депортации 2005; Лубянка 2006; и др.].

В региональной историографии первые исследования по данной теме были сделаны В. Б. Убушаевым [Убушаев 1991]. Доработанный и дополненный вариант этой книги был издан в 2007 г. [Убушаев 2007]. В последующем исследования по истории депортации калмыков и их проживания на спецпоселении стали активно развиваться, пользовались поддержкой местных властей. Было выявлено большое количество документов, часть из которых были опубликованы в различных сборниках [Ссылка калмыков 1993; Ссылка калмыков 2001], записывались воспоминания [Широкстрой 1994; Мы - из высланных 2003; Депортация 2014; Забвению не подлежит 2014; Калмыки 2019; и др.], составлялись аннотированные списки высланных с краткими биографическими сведениями [Книга Памяти 1993; Книга Памяти 1994; Книга Памяти 1998; Книга Памяти 2000; Широклаг 2000]. Значительное количество интервью было опубликовано и проанализировано Э.-Б. М. Гучиновой [Гучинова 2005б; Гучинова 2019; Гучинова 2020; и др.]. Кроме того, она провела ряд исследований об особенностях жизни калмыков на спецпоселении с точки зрения культурной антропологии [Гучинова 2005a; Гучинова 2007; Гучинова 2021; и др.]. Большое значение для изучения демографических потерь калмыков на спецпоселении имели исследования К. Н. Максимова, обобщенные им в монографии по истории советского национального строительства [Максимов 2013]. Помимо изысканий калмыцких ученых, исследования о жизни калмыков на спецпоселении осуществлялись и в трудах сибирских ученых [Зберовская 2010; Серазетдинов, Иванов 2007; Иванов 2013; Иванов 2014; и др.].

Таким образом, видно, что в постсоветский период был осуществлен значительный объем исследований по данной тематике, в том числе и по демографическим аспектам. Записано немало количество интервью калмыков-спецпоселенцев. Тем не менее большой пласт проблем, связанный с особенностями жизни и смерти калмыков на спецпоселении (как в Сибири, так и в Казахстане и Средней Азии), остается малоизученным или неизученным вовсе.

Целями настоящей статьи являются установление основного круга проблем в работе по поиску архивных материалов о жизни калмыков на спецпоселении в Сибири и постановка вопроса о необходимости их сохранения и/или дублирования.

\section{Материалы и методы}

В ходе работы был использован широкий спектр научных методов, как общенаучных (анализ, синтез и др.), так и специально-исторических (историко-генетический, историко-системный и др.). Необходимость сравнения условий хранения и доступа к фондам архивов разных регионов и разной ведомственной принадлежности обусловило активное применение историко-сравнительного метода. 


\section{Причины депортации калмыков}

27 декабря 1943 г. Президиум Верховного Совета СССР выпустил Указ, согласно которому автономия Калмыкии была ликвидирована (хотя по «сталинской» Конституции 1936 г. такого права не имел), а весь калмыцкий этнос подлежал высылке в восточные районы страны. По каким же причинам был так сурово наказан народ? В Указе от 27 декабря приводились такие причины: «многие калмыки изменили Родине, вступали в организованные немцами воинские отряды для борьбы против Красной Армии, передавали немцам честных советских граждан, захватывали и передавали немцам... колхозный скот, а после изгнания Красной Армией оккупантов организовывали банды..., совершают бандитские налеты на колхозы» [Ссылка калмыков 1993: 18-19]. Таким образом, всего было указано 4 причины, но ни одна из них не соответствовала полностью действительности. Разберем их по порядку.

Что касается угона скота, то на самом деле здесь идет речь об эвакуации скота, начавшейся после вторжения немецких войск на территорию Калмыкии в начале августа 1942 г. При этом заблаговременная эвакуация была запрещена. Должностные лица, пытавшиеся начать эвакуацию заблаговременно, подвергались наказанию за «паникерство», вплоть до арестов и расстрелов (хотя вторжение немецких войск к тому времени подтвердило их правоту). Устно (по телефону) руководству республики 4 августа 1942 г. А. И. Микояном была дана рекомендация следовать принципу «30 и 70» (эвакуацию скота начинать, когда противник окажется в 30 км, а всего остального - когда противник окажется в 70 км), хотя немцы к тому времени уже заняли два улуса и вторглись в два других [Максимов 2010: 140]. Письменный приказ об эвакуации скота прибыл лишь 4 сентября, когда немецкие и румынские войска заняли 5 улусов полностью и 3 - частично (из 13 улусов), а фронт в калмыцких степях стабилизировался. В результате приказ об эвакуации (в том числе скота) из Западного и Яшалтинского улусов вышел только 31 июля, когда туда уже вторглись панцерваффе, а из остальных улусов - 2 августа [Максимов 2010: 110, 114]. Понятно, что эвакуация проходила в обстановке хаоса и паники, была допущена потеря значительного количества имущества, в том числе оставленного на месте. По данным профессора К. Н. Максимова, который тщательно разобрал этот вопрос, перегонщикам в сложнейших условиях удалось вывести из оккупированных улусов и переправить через Волгу более $59 \%$ совхозного скота и около $20 \%$ колхозного скота (без учета того, что по пути часть скота была сдана государству и Красной армии) [Максимов 2010: 131-138]. Раскладка потерь скота по улусам дана в табл. 1. Для наглядности параллельно даны сведения о доле русского и калмыцкого населения в оккупированных улусах по данным Всесоюзной переписи 1939 г.

Таблица 1. Процент скота из оккупированных улусов,

эвакуированного через Волгу, в сопоставлении с долей русского и калмыцкого населения в тех же улусах [Максимов 2010: 132-139]

[Table 1. Shares of livestock evacuated to the left bank to the Volga River as compared to proportions of ethnic Russians and Kalmyks in population structure of same districts]

\begin{tabular}{|l|c|c|c|}
\hline Название улуса & $\begin{array}{c}\text { Спасенный } \\
\text { скот, в \% }\end{array}$ & $\begin{array}{c}\text { Русское } \\
\text { население, } \\
\text { в \% }\end{array}$ & $\begin{array}{c}\text { Калмыцкое } \\
\text { население, в \% }\end{array}$ \\
\hline Западный & 16,5 & 54,5 & 35,0 \\
\hline
\end{tabular}




\begin{tabular}{|l|c|c|c|}
\hline Яшалтинский & 15,7 & 57,9 & 20,2 \\
\hline Приютненский & 10,6 & 51,2 & 47,6 \\
\hline Троицкий & 23,4 & 47,2 & 51,4 \\
\hline $\begin{array}{l}\text { г. Элиста с пригородными } \\
\text { колхозами }\end{array}$ & 5,2 & 76,3 & 20,4 \\
\hline Сарпинский & 24,5 & 64,9 & 34,0 \\
\hline Малодербетовский & 45 & 58,3 & 40,6 \\
\hline Кетченеровский & 23,8 & 17,0 & 81,3 \\
\hline Черноземельский & 21 & 24,8 & 69,1 \\
\hline
\end{tabular}

Из указанной таблицы видно, что потери скота действительно были большими, но наибольшие потери понесли районы, в которых преобладало русское население. Конечно, это не было связано с национальностью колхозников. На уровень потерь повлияли как сугубо военно-географические факторы (направления ударов немецких войск и время захвата того или иного района), так и личностные факторы руководителей тех или иных районов, колхозов и совхозов. Тем не менее говорить о том, что калмыки потеряли намного больше скота, чем русские, не приходится.

Практически то же самое можно сказать и об утверждении, что калмыки «передавали немцам честных советских граждан», под которыми, по всей видимости, подразумеваются партизаны (почти половина из которых были калмыки) и подпольщики. Однако на самом деле случаи предательства и участие в антипартизанских акциях осуществлялись представителями разных национальностей. Например, местоположение отряда № 57 «Павел» (одного из четырех, уничтоженных в Калмыкии полностью или частично) было выдано немцам русским старостой, которому в свою очередь его сообщил родственник - партизан Ефремов, дезертировавший из этого отряда. При уничтожении отряда № 59 «Гром» немцам помогали полицейские-славяне, что частично подтверждается полицейским Коптевым, который убил в бою партизана Н. С. Чавычалова, а затем пришел к его матери и похвастался этим [Калмыкия 2006: 102]. Самая «громкая», резонансная расправа над подпольщиками в Калмыкии - казнь семей И. Т. Говенко, К. А. Макущенко и других патриотов (25 чел., в том числе 15 детей в возрасте от 2 до 15 лет), а также более 50 коммунистов, заключенных в районной тюрьме, была осуществлена 6-7 января 1943 г. полицейскими А. В. Миллером (местным немцем), Г. Е. Кониным, А. Т. Демьяновским, П. И. Прохватиловым, Ридным, Гузем и др. [Калмыкия 2006: 290-296]. Очевидно, что говорить о массовом участии в этих акциях представителей только одной национальности тоже не приходится.

Что касается коллаборационистских отрядов, то таковые создавались немцами почти на всех оккупированных территориях. В различных формированиях вермахта, войск СС, полиции и др. за весь период войны служило 1,2 млн советских граждан [Дробязко 2004: 339]. Конечно, в такой массе коллаборационистов калмыцкие эскадроны не играли сколь-нибудь значимой роли. При этом бо́льшая часть этих эскадронов была сформирована уже после изгнания немцев с территории Калмыкии из угнанной оккупантами молодежи, не призванной и не вывезенной военкоматами. Весной 1943 г. они были сведены в немецком тылу в специальное формирование, командир которого, мечтая о звании гене- 
рала, пафосно именовал его корпусом [Гучинова 2004: 38]. На самом деле в его составе было около 2-3 тыс. чел., которые имели низкую боеспособность и слабое вооружение, поэтому применялись только против партизан. Позже эту часть переименовали в полк, причем имели место переходы калмыков из его состава на сторону партизан, например, эскадрона И. С. Манцына 20 августа 1944 г. Следует учесть, что при принятии решения о высылке калмыков советское руководство еще не знало о создании этого формирования, хотя имело сведения о наличии нескольких эскадронов. Например, в справке заместителя наркома НКВД В. Н. Меркулова от 18 марта 1943 г. говорилось о создании 10 эскадронов калмыков-коллаборационистов, а также о попытке формирования добровольческого корпуса (слово «попытка» в данном контексте явно подразумевает неудачу в формировании) [Лубянка 2006: 368-369].

То же самое можно сказать и об обвинениях в бандитизме. Это явление было развито на всех территориях СССР, подвергшихся оккупации. Сведения об уровне бандитизма в некоторых регионах страны можно увидеть в табл. 2 .

Таблица 2. Сведения о борьбе с бандитизмом в некоторых регионах СССР в 1943 г. [НКВД-МВД 2008: 524-534]

[Table 2. Data on anti-banditry struggle in some regions of the USSR, 1943]

\begin{tabular}{|l|c|c|c|}
\hline \multicolumn{1}{|c|}{ Название региона } & $\begin{array}{c}\text { Количество } \\
\text { ликвидированных } \\
\text { банд }\end{array}$ & $\begin{array}{c}\text { Участников в } \\
\text { них }\end{array}$ & $\begin{array}{c}\text { Легализовано } \\
\text { после сдачи }\end{array}$ \\
\hline Калмыцкая АССР & 23 & 786 & 341 \\
\hline $\begin{array}{l}\text { Кабардино- } \\
\text { Балкарская АССР }\end{array}$ & 33 & 2398 & 130 \\
\hline $\begin{array}{l}\text { Ставропольский } \\
\text { край }\end{array}$ & 134 & 2905 & 1349 \\
\hline Краснодарский край & 207 & 2250 & - \\
\hline Дагестанская АССР & 82 & 807 & - \\
\hline $\begin{array}{l}\text { Азербайджанская } \\
\text { ССР }\end{array}$ & 163 & 748 & - \\
\hline Ростовская область & 205 & 853 & - \\
\hline Смоленская область & 164 & 1048 & - \\
\hline Калининская область & 110 & 542 & - \\
\hline Казахская ССР & 234 & 904 & - \\
\hline Киргизская ССР & 126 & & - \\
\hline
\end{tabular}

Характерно, что бандитизм был развит даже в регионах, не подвергшихся оккупации, вплоть до Дальнего Востока. Что касается Калмыкии, то к августу 1943 г. были ликвидированы все 23 банды, находившиеся в тот период в регионе, причем 43 \% членов банд амнистировали, то есть отпустили домой. В октябре 1943 г. в Калмыкию была сброшена диверсионная группа из 5 парашютистов абвера (в том числе 4 калмыка). Один калмык при этом разбился, второй калмык явился в органы НКВД и выдал всю группу. Чекисты сумели ранить и взять в плен радиста-украинца, после чего боевая ценность этой группы для абвера стала равна нулю. Тем не менее два оставшихся калмыка-коллаборациониста, используя родственные и дружеские связи, сумели организовать новую банду, но ее влияние в степи было явно слабым. Эта банда продолжала сопротивление 


\section{Источниковедение}

даже после высылки калмыцкого народа и была уничтожена уже после окончания войны, в 1945-1946 гг. [Годаев, Шурунгов 2005: 162-170].

За весь 1943 г. эти банды провели 28 налетов и провели 18 боев с отрядами НКВД, в ходе которых погибло 75 человек. Если мы посмотрим на аналогичные показатели в других регионах, в том числе не подвергавшихся оккупации, то мы увидим намного бо́льшие цифры [НКВД-МВД 2008: 524-534]. Очевидно, что обвинение целого народа в бандитизме из-за одной банды, к тому же фактически организованной вражеской спецслужбой (т. е. не по инициативе местного населения), вряд ли справедливо.

Таким образом, обвинения, выдвинутые в Указе Президиума Верховного Совета СССР от 27 декабря 1943 г., следует классифицировать как явно надуманные. К тому же они носили огульный характер и охватывали весь народ, не различая тех, кто реально сотрудничал с врагом, от тех, кто оккупантов, что называется, «в глаза не видел», и тех, кто доблестно воевал с фашистами на фронте. Между тем в составе Красной армии в годы Великой Отечественной войны сражалось почти 26 тыс. калмыков (т. е. почти каждый пятый из 134 тыс. калмыков, учтенных по Всесоюзной переписи 1939 г.), из которых 13,5 тыс. погибли или пропали без вести, а еще 8,5 тыс. - ранены (часть из них стала инвалидами). Характерный штрих: если соотнести количество населения по данным Всесоюзной переписи 1939 г. с количеством Героев Советского Союза, удостоенных за подвиги в период Великой Отечественной войны, то калмыки окажутся на 6-м месте в списке народов СССР (см. табл. 3).

Таблица 3. Соотношение численности населения (в тыс.) различных национальностей к количеству Героев Советского Союза, присвоенных за отличия в Великой Отечественной войне

[Table 3. Proportions between ethnic population sizes (thousand) and numbers of Heroes of the Soviet Union during the Great Patriotic War]

\begin{tabular}{|l|c|c|c|}
\hline Национальность & $\begin{array}{c}\text { Численность } \\
\text { населения по } \\
\text { переписи 1939 г. } \\
\text { (в тыс. чел.) }\end{array}$ & $\begin{array}{c}\text { Количество Героев } \\
\text { Советского Союза } \\
\text { соответствующей } \\
\text { национальности* }\end{array}$ & $\begin{array}{c}\text { Итоговый } \\
\text { коэффициент }\end{array}$ \\
\hline Осетины & 354 & 32 & 11,06 \\
\hline Русские & 99592 & 8182 & 12,17 \\
\hline Украинцы & 28111 & 2072 & 13,57 \\
\hline Адыгейцы & 88 & 6 & 14,67 \\
\hline Абхазы & 59 & 4 & 14,75 \\
\hline Калмыки & 134 & 9 & 14,88 \\
\hline Белорусы & 5275 & 309 & 21,64 \\
\hline Башкиры & 844 & 39 & 23,87 \\
\hline Мордовцы & 1456 & 90 & 23,92 \\
\hline Армяне & 2153 & 61 & 1991 \\
\hline
\end{tabular}

* Количество Героев Советского Союза уточнено по данным на 1991 г.

Если же провести аналогичные расчеты с переписью 1959 г., то из-за огромных демографических потерь, произошедших в результате депортации, делимое 
заметно уменьшится, и калмыки вовсе переместятся на 2-е место, что и нашло отражение в публикации одного из авторов [Очиров 2019: 176-178].

Таким образом, обвинения, приведенные в Указе Президиума Верховного Совета СССР, совершенно несправедливы и огульны, без разбора реальной вины тех или иных людей.

\section{Выселение калмыков}

Выселение осуществлялось в несколько этапов. Первоначально (28 декабря 1943 г.) было выселено калмыцкое население из Калмыцкой АССР, Калмыцкого района Ростовской области, а также Ставропольского края. В ходе этой операции под названием «Улусы» было выселено 93139 калмыков, в том числе 43254 детей (26 369 семей) [Ссылка калмыков 1993: 123]. В январе 1944 г. было довыслано еще 64 семьи, которых упустили во время операции «Улусы». При этом многим калмыкам не объяснили, в какой регион (жаркий или холодный) и на какой срок они высылаются, не объявляли разрешенный объем груза (до 500 кг на семью), торопили при погрузке, не давая времени на сборы вещей и продовольствия. В панике старики и женщины не могли сообразить, что следует брать, грузили ненужные вещи или вовсе бросали все имущество. Эта поспешность в сборах в дальнейшем сыграла свою роковую роль. Многие из тех, кто не смог правильно подготовиться к депортации, умерли. И, наоборот, те калмыки, которым офицеры и солдаты НКВД оказали помощь, давали время на погрузку и забой скота, советы о том, какие вещи и продукты следует брать, смогли выжить.

Калмыки были погружены в 46 эшелонов, которые направлялись в регионы Сибири: в Алтайский и Красноярский края, Новосибирскую и Омскую области. В ходе высылки один из эшелонов (648 семей) был повернут на Аральское море, где потребовались опытные рыбаки (Кзыл-Ординскую область Казахской ССР). Конкретные цифры распределения по регионам калмыков, высланных в декабре 1943 г. — январе 1944 г. приведены в табл. 4.

Таблица 4. Сведения о количестве калмыков, высланных в регионы Сибири и Казахстана в декабре 1943 г. — январе 1944 г.

[Table 4. Numbers of Kalmyks deported to regions of Siberia and Kazakhstan, December 1943 to January 1944]

\begin{tabular}{|l|c|c|c|c|c|}
\hline & Семей & Мужчин & Женщин & $\begin{array}{c}\text { Детей до } \\
16 \text { лет }\end{array}$ & Всего чел. \\
\hline Алтайский край & 6469 & 4269 & 7524 & 10420 & 22123 \\
\hline $\begin{array}{l}\text { Красноярский } \\
\text { край }\end{array}$ & 7528 & 4448 & 8845 & 11705 & 24998 \\
\hline $\begin{array}{l}\text { Новосибирская } \\
\text { область }\end{array}$ & 5455 & 3579 & 5605 & 7252 & 16436 \\
\hline Омская область & 8468 & 4701 & 9559 & 12898 & 27158 \\
\hline $\begin{array}{l}\text { Кзыл-Ординская } \\
\text { область }\end{array}$ & 648 & 509 & 780 & 979 & 2268 \\
\hline
\end{tabular}




\section{Источниковедение}

Вагоны были скотскими, не предназначенными для перевозки людей (как писалось в документах НКВД - «вагоны без нар, без окон, печи без колосников, большие щели»), плохо отапливались. В пути отсутствовало регулярное горячее питание, медицинская помощь. Все это привело к значительной смертности. По данным на 27 января 1944 г. (когда первый этап выселения был завершен) 1640 калмыков умерло в пути следования, в том числе 642 ребенка, 262 взрослых (в возрасте от 16 до 40 лет) и 736 стариков. Среди причин смертности были указаны: воспаление легких - 488, желудочно-кишечные заболевания - 341, истощение - 227 и т. д. Следует заметить, что не все районы подготовились к приему спецпоселенцев, поэтому были случаи, когда калмыцким семьям приходилось по несколько дней или даже недель ждать «приемщиков» в неотапливаемых зданиях станций, что также отразилось на их смертности: 401 калмык умер во время разгрузки. Еще 1010 калмыков госпитализировали в пути [Ссылка калмыков 1993: 123].

Как раз в этот период (март 1944 г.) система надзора за спецпоселенцами (районные и поселковые спецкомендатуры НКВД) была выделена из региональных структур и подчинена вновь созданной структуре наркомата - отделу спецпоселений НКВД СССР.

В последующем органы НКВД начали учет калмыков в других регионах СССР, после чего их также высылали в Сибирь.

25 марта 1944 г. 2628 калмыков (548 семей) было выслано из районов Ростовской области, ранее не охваченных операцией «Улусы» (Сальский, Дубовский, Котельниковский и др.). 8 апреля 1944 г. эшелон прибыл в Новосибирск. В эшелоне доехало 2536 калмыков (489 мужчин, 881 женщина, 1166 детей), притом, что в пути умерло 12 чел. (в том числе 5 детей) [Ссылка калмыков 1993: 84-90]. Однако разница между количеством высланных и прибывших в пункт назначения составила 92 чел.

Из вновь образованной Астраханской области весной 1944 г. было довыслано еще две группы калмыков. 20 марта 1944 г. в Омскую область прибыло 89 калмыков из районов бывшего Астраханского округа. 15 апреля 1944 г. Л. П. Берия приказал провести новую «зачистку» в Астраханской области (бывших районах Калмыкии). К 1 мая в результате «прочесывания калмыцких степей» было выявлено и отправлено еще 400 калмыков [Бугай 1991: 36].

2 июня 1944 г. началась операция по выселению калмыков из Сталинградской области. Эшелон, в который было погружено 1169 калмыков (387 семей), прибыл в Свердловскую область 12 июня и сдал 1178 калмыков (287 мужчин, 357 женщин, 534 ребенка), притом, что в пути умерло 5 чел. (в том числе 3 детей) [Ссылка калмыков 1993: 94].

Кроме того, началось снятие с фронтов калмыков-военнослужащих. К началу 1944 г. в составе Красной армии служило 6,8 тыс. калмыков, из которых в течение 1944 г. были демобилизованы и направлены на спецпоселение 102 офицера и 605 сержантов и рядовых из числа инвалидов и больных. Еще 3443 сержантов и рядовых были направлены в Широковский исправительно-трудовой лагерь ГУЛАГ НКВД СССР для строительства Широковской ГЭС [Максимов 2010: 345]. Калмыки-военнослужащие прибывали в Широклаг и в 1945 г., правда, уже в небольших количествах. В этом лагере калмыков использовали на самых 


\section{Монголоведение • Mongolian Studies • 2021 • T. 13 • № 4}

тяжелых и опасных работах. Из-за тяжелых условий труда, невыполнимых норм, плохого питания солдаты-«широклаговцы» быстро доходили до стадии истощения. Многие военнослужащие (которые ранее были здоровыми молодыми мужчинами, годными для службы в армии) стали умирать от дистрофии, деменции, пеллагры, преждевременного одряхления организма [Широклаг 2000: 5]. По данным Н. К. Шарапова, работавшего в Широклаге в отделе статистики, только за год умерло 911 из 3,6 тыс. калмыков [Широкстрой 1994: 138]. Лишь весной 1945 г., когда стало понятно, что без турбоагрегатов форсированное строительство ГЭС бессмысленно, «широклаговцев» начали демобилизовать и отправлять к родственникам, на спецпоселение [Очиров, Воробьева 2020: 354-355].

После окончания войны из Красной армии в 1945 г. было демобилизовано 1605 калмыков (без учета широклаговцев). Кроме того, из немецкого плена было репатриировано 4327 калмыков-военнослужащих и 2318 калмыков-гражданских из числа угнанных в Германию [Максимов 2013: 329]. Какая-то часть из них была осуждена и отбывала полученные сроки в лагеря ${ }^{1}$, часть отправилась домой или к родственникам, на места спецпоселений, а оставшиеся были направлены на различные предприятия или отдаленные районы сроком на 6 лет, в статусе тех же спецпоселенцев. Из Астраханской и Ростовской областей в 1945-1948 гг. довыселялись не выявленные ранее калмыки, но, как правило, это были демобилизованные или репатриированные (которых мы уже учли ранее). Наконец, в декабре 1948 г. на учет были взяты 932 калмыка из числа высланных во время борьбы с кулачеством (Казахстан, Киргизия, Тюменская, Новосибирская, Томская и Свердловская области) и еще 106 калмыков, проживавших в других регионах, не подвергшихся спецоперации [Максимов 2013: 347]. Кроме того, к 1949 г. на спецпоселение прибыло 1035 калмыков, освобожденных из мест заключений.

Таким образом, мы можем говорить о том, что в 1949 г. в общей сложности на спецпоселении должно было оказаться более 116 тыс. калмыков. По данным Всесоюзной переписи 1939 г. в СССР проживало 134 тыс. калмыков, включая около 3 тыс. киргизских сарт-калмыков, которые не являлись калмыками и не подвергались репрессиям. Если из оставшейся цифры вычесть более 9 тыс. калмыков, погибших на фронтах Великой Отечественной, неизвестное количество гражданского населения, погибшего в годы войны или не вернувшегося после угона на запад, то можно прийти к выводу о том, что почти весь калмыцкий народ оказался выслан на спецпоселение.

\section{Проживание на спецпоселении}

Первоначально калмыки расселялись в Алтайский и Красноярский края, Новосибирскую и Омскую области РСФСР. В ходе высылки один из эшелонов был повернут на Арал (Кзыл-Ординскую область). Так образовались первые спецпоселения калмыков в Казахстане, а затем и в Узбекистане. В июне 1944 г. калмыки из Сталинградской области были выселены в Свердловскую область. В августе 1944 г. из состава Новосибирской области выделилась Томская область, из состава Омской и Курганской областей - Тюменская область. В

${ }^{1}$ По данным на 1947 г., в местах заключения значились 1530 калмыков (включая 16 детей), на 1 июля 1952 г. — 2072 калмыка [Максимов 2013: 344, 353]. 


\section{Источниковедение}

последующем крупные группы калмыков вербовались на работы в сложных климатических условиях: в Ханты-Мансийский и Ямало-Ненецкий округа, Якутию, на Сахалин и т. д. Кроме того, калмыки старались перебраться в более привычные условия - в Казахстан и Киргизию. Таким образом, калмыки-спецпереселенцы оказались рассеяны на огромных просторах, вплоть до Ледовитого и Тихого океанов.

Сам процесс выселения осуществлялся с большой поспешностью. Фининспекторы за день-два до начала депортации постарались собрать с калмыков максимально возможный объем налогов, взыскали все недоимки. Огромное количество имущества, скота и др. пропало. В ряде случаев сотрудники НКВД отбирали деньги, понравившиеся им вещи. Прием имущества и скота, оставляемого в Калмыкии, осуществлялся с нарушениями или не осуществлялся вовсе. Даже в тех случаях, когда происходил прием скота, соответствующие квитанции на руки спецпереселенцам не выдавались. Во многих калмыцких селах, где не осталось населения, «скот ходил в степи без призора» [Ссылка калмыков 1993: 124], расхищался или просто вымер без ухода людей. По оценке старшего инспектора контрольно-инспекторского отдела ГУЛАГ НКВД СССР Полюдова из предполагаемых 142 тыс. голов скота было принято 120 тыс. [Ссылка калмыков 1993: 124].

В результате этого при выселении калмыков фактически лишили большей части имущества. Многочисленные нарушения инструкции по выселению, поспешность в сборах в дальнейшем сыграли свою роковую роль. Как упоминалось выше, только в первой волне от голода и холода в пути и при разгрузке умерло более 2 тыс. калмыков, еще более 1 тыс. заболело. Однако еще большие демографические потери произошли у калмыков после прибытия на места спецпоселений. Инструкция требовала расселять калмыков только на территориях колхозов, совхозов и лесхозов. Им запрещалось селиться на территориях городов, где они могли быстрее всего найти работу и, соответственно, пропитание для себя. Позже некоторым удалось устроиться на работу в городах, но первоначально калмыков старались расселять исключительно в сельской местности. И если совхозы и лесхозы были обязаны брать к себе таких спецпоселенцев (состоявших большей частью из стариков, женщин и детей), то колхозы (как кооперативные объединения) формально имели право не принимать в свой состав (и, соответственно, не предоставлять им работы) новых насельников. Даже после приема на работу новые члены колхозов только начинали получать трудодни, которые «обналичить» в виде денег или натуральных продуктов они могли не скоро. Многие калмыки, особенно из числа тех, кто не получил работу, и нетрудоспособных иждивенцев были вынуждены искать посторонние источники пропитания: продавали привезенные вещи (в том числе одежду и обувь), занимались собирательством в лесу, нанимались на поденную работу, просили подаяние и т. д. Неудивительно, что вскоре большинство калмыков-спецпереселенцев оказались в состоянии полной нищеты.

Распределяя калмыков по селам, органы НКВД требовали от руководства хозяйств заселять спецпоселенцов в пустующие здания (клубы, сараи, амбары, бани, шалаши и прочие помещения, неприспособленные для проживания) или бесплатно подселять к местным жителям, что не вызывало большой радости у последних. Начальник НКВД по Новосибирской области Ф. П. Петровский и 


\section{Монголоведение • Mongolian Studies • 2021 • T. 13 • № 4}

начальник отдела спецпоселений УНКВД Новосибирской области Г. С. Жуков писали в своем докладе начальнику отдела спецпоселений НКВД СССР полковнику госбезопасности М. В. Кузнецову, что «на 1 октября 1944 г. из 5818 семей калмыков, расселенных в области только 682 семьи (11\%) имели сколько-нибудь пригодные к зиме жилища... до 80 \% калмыков, особенно проживающих в сельской местности, были разуты и раздеты» [История сталинского Гулага 2004: 450-451].

Заместитель наркома НКВД В. В. Чернышев 19 апреля 1944 г., анализируя положение калмыков-спецпоселенцев в Омской области, писал, что из 8,4 тыс. семей калмыков почти 5,5 тыс. оказались размещены «в порядке уплотнения местных жителей. Благодаря этому многие спецпереселенцы находятся в тяжелых жилищно-бытовых условиях» [Ссылка калмыков 1993: 151]. Мало того, значительная часть колхозов области свое право не принимать новых колхозников использовала отнюдь не формально. Из 12677 калмыков, расселенных в колхозах Омской области, к апрелю 1944 г. в колхозы вступило всего 3738 чел. При этом в 7 районах из 19, предназначенных для расселения спецпоселенцев, ни один калмык не вступил в колхоз. Все это привело к голоду, истощению людей, росту заболеваемости, появлению эпидемий и повышенной смертности. Всего за период с 22 января по 10 марта 1944 г. в Омской области умерло 475 калмыков. 18 апреля 1944 г. нарком госбезопасности СССР В. Н. Меркулов в докладной записке наркому НКВД Л. П. Берии, описывая положение калмыков в Омской области, констатировал, что в январе-феврале от недоедания только в Исиль-Кульском районе умерло 109 калмыков. Например, в колхозе им. Коминтерна в 8 маленьких домах было размещено 122 калмыка, из которых 25 чел. уже умерли от недоедания. При этом имели место случаи гибели целых семейств. 10 семей в колхозе лежали опухшими от голода [Ссылка калмыков 1993: 150].

Не лучше положение калмыков было в лесхозах и совхозах. На Томский лесоперевалочный комбинат было направлено 399 семей (1 415 калмыков, включая стариков и детей). Руководство комбината расселило их, где только могло, в основном, в помещениях, не приспособленных для проживания. Скученность в них была большая, в комнатах не было стекол, печи дымили в помещения. Вышеупомянутый Г. С. Жуков, проведший инспекцию комбината 4-5 ноября 1944 г., писал, что у калмыков «жилфонд не превышает полутора квадратных метров на человека». К началу проверки умерло уже 103 калмыка, в основном от дистрофии и туберкулеза. Из 240 калмыков, подвергнутых медосвидетельствованию, 58 оказались с тяжелой формой дистрофии, $10-$ с открытой формой туберкулеза, 31 - со скрытой формой туберкулеза. Из 501 калмыка, прошедших врачебную комиссию, 244 оказались инвалидами, 54 - «в силу истощения... годны только к легкому физическому труду» [Ссылка калмыков 1993: 170]. 58 семей калмыков (189 человек, в том числе 97 детей), поселенных на комбинате, оказались вообще не трудоспособными. Они выживали только за счет продажи половины хлеба, полученного по иждивенческим карточкам. Комбинат обеспечил трудоспособных трехразовым питанием, «но у многих калмыков не хватает денег, чтобы выкупать обеды» [Ссылка калмыков 1993: 170]. Семьям спецпереселенцев выделили огороды, но из-за отсутствия семян они были засеяны плохо. «Особенно остро обстоит дело с одеждой и обувью. До 


\section{Источниковедение}

75 \% всех калмыков совершенно не имеют сколь-нибудь пригодной для зимы одежды и обуви... Нередки случаи, когда... в условиях начавшихся морозов люди работают полураздетыми и полубосыми... В бараках нередко встречаются совершенно голые дети, среди них — рахитики, опухшие...» [Ссылка калмыков 1993: 170].

Власти предпринимали попытки по помощи калмыкам-спецпереселенцам: выделяли ссуды, продовольственную и иную материальную помощь, приусадебные участки и огороды. Калмыков (как и других спецпереселенцев) освободили от сельхозналогов за 1945 г. Тем не менее первые годы на спецпоселении среди калмыков была очень высокая смертность, особенно детская. По данным К. Н. Максимова, в 1944 г. в Алтайском крае умерло 2507 калмыков (11,3\% от числа принятых), в том числе 1861 (8,4\%) - в первом полугодии, в Красноярском крае - 3538 калмыков (14,15\%), в том числе 2009 (8,04\%) — в первом полугодии, в Новосибирской области - 1510 калмыков $(8,4 \%)$, в Томской области - 261 калмык $(17,4 \%)$, в Омской области (в границах сентября 1944 г.) - 1856 калмыков (16,3\%), в Тюменской области - 1755 калмыков (12,3 \%), в Свердловской области - 106 калмыков (9,04 \%) [Максимов 2013: 315-319]. Сведения о количестве умерших и вновь родившихся в 1944-1952 гг. калмыков-спецпоселенцев, выявленные К. Н. Максимовым, приведены в табл. 5.

Таблица 5. Смертность и рождаемость калмыков-спецпереселенцев в 1945-1952 гг.

[Максимов 2013: 319, 344, 350, 352]

[Table 5. Death and birth rates among repressed Kalmyks, 1945-1952]

\begin{tabular}{|l|c|c|}
\hline \multicolumn{1}{|c|}{ Год } & Родилось & Умерло \\
\hline 1944 г. & $?$ & 11717 (в том числе 4 210 детей) \\
\hline 1945 г. & 351 & 8329 (в том числе 3 735 детей) \\
\hline 1946 г. & 628 & 2187 \\
\hline 1947 г. & 757 & 2358 \\
\hline 1948 г. & 1135 & 2766 \\
\hline 1949 г. & 2058 & 1903 \\
\hline 1950 г. & 2914 & 2257 \\
\hline $1951-1952$ гг. & 4242 & 3104 \\
\hline
\end{tabular}

Как видно, цифры демографических потерь по данным отдела спецпоселений весьма велики, на наш взгляд, они явно не полные. Например, в 1944 г. в места спецпоселений было выселено как минимум 98 тыс. калмыков (без учета широклаговцев), что за вычетом 11,7 тыс. умерших должно было дать 86 тыс. чел. Но по справке отдела спецпоселений НКВД СССР на 1 октября 1944 г. (т. е. даже не на конец года) значилось 83688 калмыков [Ссылка калмыков 2001: 145]. Очевидно, что количество умерших калмыков было заметно больше.

Тем не менее указанные цифры отдела спецпоселений хорошо показывают динамику смертности калмыков. Через три года на спецпоселении значилось 74918 калмыков, а еще 1364 калмыка были освобождены от учета. Тогда же всем спецпереселенцам был объявлен Указ Президиума Верховного совета СССР от 26 ноября 1948 г. о том, что выселение произведено «навечно», а за побег с мест спецпоселений грозили 20-летней каторгой. Сразу после этого 


\section{Монголоведение • Mongolian Studies • 2021 • T. 13 • № 4}

был произведен переучет спецпереселенцев, который выяснил, что на учете значилось 73727 калмыков, а еще 268 - бежало с мест поселения (в том числе 141 $1^{1}$ - в 1945-1947 гг., 127 - в 1948 г.) [Бугай 1991б: 71]. Характерно, что лишь в 1949 г. рождаемость у калмыков стала хоть ненамного, но превышать смертность (на 8 \%). С этого периода можно говорить о том, что жизнь и быт калмыков-спецпереселенцев наладились хотя бы в минимальной степени, тяжелый период первой адаптации завершился. Однако в жизни калмыков продолжали сохраняться серьезные ограничения, в том числе на поступление в вузы и службе в армии.

По данным на 1 января 1953 г. на учете органов МГБ СССР значилось 81475 калмыков [Ссылка калмыков 1993: 232], из которых 79376 чел. (23 098 мужчин, 30360 женщин, 25918 детей до 16 лет) находились на спецпоселении, 2040 чел. - в местах заключения, 59 - числились бежавшими [Максимов 2013: 355]. После смерти И. В. Сталина положение спецпереселенцев заметно облегчилось, причем инициаторами этих послаблений выступили органы госбезопасности во главе с Л. П. Берией. В 1953 г. были разрешены командировки в другие районы, в 1954 г. - с учета были сняты дети до 16 лет и студенты-спецпоселенцы, а ежемесячная регистрация взрослых была заменена на ежегодную, в 1955 г. - с учета были сняты участники Великой Отечественной войны, кавалеры орденов и медалей. В марте 1956 г. административный надзор органов МВД над калмыками был отменен полностью, но возвращение на родину им запрещалось. Лишь 9 января 1957 г. автономия Калмыкии была восстановлена в форме автономной области, а калмыкам разрешили вернуться на родину. Словосочетание «13 лет 13 дней» стало в народе устойчивой фольклорной формулой, обозначающей в истории калмыцкого народа период депортации.

Во второй части статьи будут рассмотрены проблемы поиска и сохранения архивных материалов о жизни калмыков на спецпоселении в Сибири в 1944-1957 гг.

\section{Источники}

Депортации 1992 - Депортации народов СССР (1930-1950-е годы). Ч. 1. Документальные источники ЦГАОР. Материалы к серии «Народы и культуры». Вып. XII / сост. О. Л. Милова. М.: ИЭА РАН, 1992. 353 с.

Депортация 2014 - Депортация в памяти поколений / сост. С. Э. Лиджи-Горяева и др. Элиста: Джангар, 2014. 294 с.

Забвению не подлежит 2014 - Забвению не подлежит / сост. И. В. Лиджиева, К. Э. Манцева. Элиста: КИГИ РАН, 2014. 163 с.

Из истории 2001 - Из истории земли томской. 1940-1956. Невольные сибиряки: Сб. док. и материалов / сост.: И. В. Нам и др. Томск: Гос. арх. Том. обл., 2001. 349 с.

Иосиф Сталин 1992 - Иосиф Сталин - Лаврентию Берия: «Их надо депортировать»: Документы, факты, комментарии / сост. Н. Ф. Бугай. М.: Дружба народов, 1992. $288 \mathrm{c}$.

История сталинского Гулага 2004 - История сталинского Гулага. Конец 1920-х - первая половина 1950-х годов: Собр. док-тов в 7 т. Т. 5. Спецпереселенцы в СССР / отв. ред. и сост. Т. В. Царевская-Дякина. М.:РОССПЭН, 2004. 824 с.

${ }^{1}$ Имелось в виду, из числа еще не пойманных. Только в январе-мае 1944 г. с мест спецпоселений бежало (или были признаны бежавшими) 278 калмыков, но 138 из них были пойманы [История сталинского Гулага 2004: 439]. 


\section{Источниковедение}

Калмыки 2019 - Калмыки. Депортация. Возвращение: к 75-летию депортации калмыцкого народа / Сост. С. Э. Лиджи-Горяева и др. Элиста: ИКИАТ, 2014. 519 с.

Калмыкия 2006 - Калмыкия в партизанском движении 1941-1945 гг.: документы и материалы. Элиста: Калм. кн. изд-во, 2006. 432 с.

Книга Памяти 1993 - Книга Памяти ссылки калмыцкого народа. Т. 2. Кн. 1. А-К. Высланы... Оставлены навечно / отв. за вып. Т. Ф. Овшинова. Элиста: Калм. кн. изд-во, 1993. 336 с.

Книга Памяти 1994 - Книга Памяти ссылки калмыцкого народа. Т. 2. Кн. 2. Л-Я. Высланы... Оставлены навечно... / отв. за вып. Т. Ф. Овшинова. Элиста: Калм. кн. изд-во, 1994. 544 с.

Книга Памяти 1998 - Книга Памяти ссылки калмыцкого народа. Т. 2. Кн. 3. А-Я. Высланы... Оставлены навечно... / ред. совет: К. Н. Илюмжинов (пред.). Элиста: Калм. кн. изд-во, 1998. 574 с.

Книга Памяти 2000 - Книга Памяти ссылки калмыцкого народа. Т. 2. Кн. 4. А-Я. Высланы... Оставлены навечно... / ред. совет: В. А. Бембетов, А. В. Дорждеев и др. Элиста: Калм. кн. изд-во, 2000. 343 с.

Лубянка 2006 - Лубянка. Сталин и НКВД-НКГБ-ГУКР «СМЕРШ». 1939 - март 1946 / Архив Сталина. Документы высших органов партийной и государственной власти / Сост. В. Н. Хаустов, В. П. Наумов, Н. С. Плотникова. М.: МФД; Материк, 2006. $640 \mathrm{c}$.

Мы - из высланных 2003 - Мы - из высланных навечно. Воспоминания депортированных калмыков (1943-1957 гг.) / сост. и ред. П. О. Годаев. Элиста: АПП «Джангар», 2003. $464 \mathrm{c.}$.

НКВД-МВД СССР 2008 - НКВД-МВД СССР в борьбе с бандитизмом и вооруженным националистическим подпольем на Западной Украине, в Западной Белоруссии и Прибалтике (1939-1956): Сборник документов. М.: Объединенная редакция МВД, 2008. 369 с.

Ссылка калмыков 1993 - Книга Памяти ссылки калмыцкого народа. Т. 1. Ссылка калмыков: как это было: Сборник документов и материалов. Кн. 1 / сост. П. Д. Бакаев, Н. Ф. Бугай, Л. С. Бурчинова и др. Элиста: Калм. кн. изд-во, 1993. 264 с.

Ссылка калмыков 2001 - Книга Памяти ссылки калмыцкого народа. Т. 1. Ссылка калмыков: как это было: Сборник документов и материалов. Кн. 2 / сост. В. 3. Атуева, Л. С. Бурчинова, С. А. Гладкова и др. Элиста: Калм. кн. изд-во, 2001. 237 с.

Сталинские депортации 2005 - Сталинские депортации. 1928-1953 гг. / сост. Н. Л. Поболь, П. М. Полян. М.: МФД; Материк, 2005. 904 с.

Широклаг 2000 - Широклаг. Широкстрой: Списки калмыков-военнослужащих рядового и сержантского состава, отозванных с фронтов в 1944-1945 гг. (Книга памяти ссылки калмыцкого народа. Т. 3. Кн. 1) / сост. А. Б. Баирова, Т. Ч. Бембеева, С. Э. Лиджи-Горяева, Р. В. Неяченко. Элиста: Калм. кн. изд-во, 2000. 294 с.

Широкстрой 1994 - Широкстрой: Широклаг: Сб. воспоминаний воинов-калмыков, участников строительства Широковской ГЭС / сост. и вступ. ст. Р. В. Неяченко. Элиста: Джангар, 1994 (Книга памяти ссылки калмыцкого народа. Т. 3. Кн. 2). $190 \mathrm{c}$.

\section{Sources}

Atueva V. Z. (comp.) Kalmykia in Guerrilla Movements, 1941-1945. Documents and materials. Elista: Kalmykia Book Publ., 2006. 432 p. (In Russ.)

Atueva V. Z. et al. (comps.) Memorial Book of Kalmyk Deportation. Vol. 1. Book 2: Kalmyk Deportation. How It Was. Collected documents and materials. Elista: Kalmykia Book Publ., 2001. 237 p. (In Russ.)

Bairova A. B. et al. (comps.) Memorial Book of Kalmyk Deportation. Vol. 3. Book 1: Shirokstroy. Shiroklag. Name lists of Kalmyk soldiers and non-commissioned officers 
withdrawn from front line combat service in 1944-1945. Elista: Kalmykia Book Publ., 2000. 294 p. (In Russ.)

Bakaev P. D. et al. (comps.) Memorial Book of Kalmyk Deportation. Vol. 1. Book 1: Kalmyk Deportation. How It Was. Collected documents and materials. Elista: Kalmykia Book Publ., 1993. 264 p. (In Russ.)

Bugay N. F. (comp.) Joseph Stalin — Lavrentiy Beria: 'Be Those Deported'. Documents, Facts, Comments. Moscow: Druzhba Narodov, 1992. 288 p. (In Russ.)

Godaev P. O. (comp., ed.) We Are the Forever Deported: Memoirs of Repressed Kalmyks, 1943-1957. Elista: Dzhangar, 2003. 464 p. (In Russ.)

Khaustov V. N., Naumov V. P., Plotnikova N. S. (comps.) Lubyanka. Stalin and NKVDNKGB-SMERSH, 1939 - March 1946. Stalin's Archives. Documents of Supreme Party and Government Authorities. Moscow: MFD; Materik, 2006. 640 p. (In Russ.)

Lidzhieva I. V., Mantseva K. E. Never Be Forgotten. Elista: Kalmyk Humanities Research Institute (RAS), 2014. 163 p. (In Russ.)

Lidzhi-Goryaeva S. E. et al. (comps.) Deportation in Memories of Generations. Elista: Dzhangar, 2014. 294 p. (In Russ.)

Lidzhi-Goryaeva S. E. et al. (comps.) Kalmyks. Deportation. Return: Towards the 75th Anniversary of Kalmyk Deportation. Elista: IKIAT, 2014. 519 p. (In Russ.)

Memorial Book of Kalmyk Deportation. Vol. 2. Book 3: A-Я. The Deported and Left behind Forever. Executive Office of the President of the Republic of Kalmykia. Elista: Kalmykia Book Publ., 1998. 574 p. (In Russ.)

Memorial Book of Kalmyk Deportation. Vol. 2. Book 4: A-Я. The Deported and Left behind Forever. Executive Office of the President of the Republic of Kalmykia. Elista: Kalmykia Book Publ., 2000. 343 p. (In Russ.)

Milova O. L. (comp.) Soviet Peoples Deported, 1930s-1950s. Part 1: Documentary Sources from the October Revolution Central State Archive. Ser. 'Peoples and Cultures'. Vol. XII. Moscow: Institute of Ethnography and Anthropology (RAS), 1992. 353 p. (In Russ.)

Nam I. V. et al. (comps.) Tomsk Land, 1940-1956: Glimpses of History. The Forced Siberians. Collected documents and materials. Tomsk: State Archive of Tomsk Oblast, 2001. 349 p. (In Russ.)

Neyachenko R. V. (comp.), Oglaev Yu. O. (ed.) Memorial Book of Kalmyk Deportation. Vol. 3. Book 2: Shirokstroy. Shiroklag. Collected memoirs of survived Kalmyk Red Army servicemen on Shirokovsky Forced Labor Camp. Elista: Dzhangar, 1994. 190 p. (In Russ.)

Ovshinova T. F. (ed.) Memorial Book of Kalmyk Deportation. Vol. 2. Book 1: A-K. The Deported and Left behind Forever. Elista: Kalmykia Book Publ., 1993. 336 p. (In Russ.) Ovshinova Т. F. (ed.) Memorial Book of Kalmyk Deportation. Vol. 2. Book 2: Л-Я. The Deported and Left behind Forever. Elista: Kalmykia Book Publ., 1994. 544 p. (In Russ.)

Pobol N. L., Polyan P. M. (comps.) Stalin's Deportations, 1928-1953. Moscow: MFD; Materik, 2005. 904 p. (In Russ.)

Tsarevskaya-Dyakina T. V. (comp., ed.) A History of Stalin's Gulag, Late 1920s to Mid1950s. Collected documents. In 7 vols. Vol. 5: Forced Settlers in the USSR. Moscow: ROSSPEN, 2004. 824 p. (In Russ.)

Vladimirtsev N. I., Kokurin A. I. (comps.) NKVD-MVD of the USSR: Struggling against Banditry and Nationalist Resistance Movements in Western Ukraine, Western Belorussia and the Baltic, 1939-1956. Collected documents. Moscow: Ministry of Internal Affairs of Russia, 2008. 369 p. (In Russ.)

\section{Литература}

Бугай 1989 - Бугай Н. Ф. К вопросу о депортации народов СССР в 30-40-х годах // История СССР. 1989. № 6. С. 135-144. 


\section{Источниковедение}

Бугай $1991 \mathrm{a}-$ Бугай Н. Ф. Погружены в эшелоны и отправлены к местам поселений...

Л. Берия - И. Сталину // История СССР. 1991. № 1. С. 143-165.

Бугай 19916 - Бугай Н. Ф. Операция «Улусы». Элиста: [б. и.], 1991. 88 с.

Бугай 1992а - Бугай Н. Ф. 40-50-е годы: последствия депортации народов (свидетельствуют архивы НКВД-МВД СССР) // Отечественная история. 1992. № 1. С. 122143.

Бугай 19926 - Бугай Н. Ф. 20-40-е годы: депортация населения с территории Европейской России // Отечественная история. 1992. № 4. С. 37-49.

Бугай 1995 - Бугай Н. Ф. Л. Берия - И. Сталину: «Согласно вашему указанию...». М.: АИРО-ХХ, 1995. 320 c.

Бугай 2011 - Бугай Н. Ф. Л. Берия - И. Сталину: «После Ваших указаний проведено следующее...». М.: Гриф и К, 2011. 507 с.

Годаев, Шурунгов 2005 - Годаев П. О., Шурунгов А. Б. Операция «Парашютисты» // Во имя безопасности России. Элиста: УФСБ РФ по Республике Калмыкия, 2005. C. $159-170$.

Гучинова $2004-$ Гучинова Э.-Б. Улица «Kalmuk Road»: История, культура и идентичности в калмыцкой общине США. СПб.: Алетейя, 2004. 328 с.

Гучинова 2005a - Гучинова Э.-Б. Помнить нельзя забыть. Антропология депортационной травмы калмыков. Stuttgart: Ibidem-Verlag, 2005. 283 с.

Гучинова 20056 - Гучинова Э.-Б. У каждого своя Сибирь. Два рассказа о депортации калмыков // Антропологический форум. 2005. № 3. С. 400-444.

Гучинова 2007 - Гучинова Э.-Б. «Я - высланная, ты - без ноги». Депортация калмыков (1943-1956): гендерный взгляд // Acta Slavica Iaponica. 2007. Т. 24. P. 74-99.

Гучинова 2019 - Гучинова Э.-Б. У каждого своя Сибирь. Две истории о депортации калмыков (интервью с С. М. Ивановым и С. Э. Нарановой) // Oriental Studies. 2019. T. 12. № 3. C. 397-422. DOI: 10.22162/2619-0990-2019-43-3-397-422

Гучинова 2020 - Гучинова Э.-Б. У каждого своя Сибирь. Годы войны и депортации в монологах Л. Т. Дорджиева и Е. С. Басановой // Oriental Studies. 2020. Т. 13. № 4. C. 976-1011. DOI: 10.22162/2619-0990-2020-50-4-976-1011

Гучинова 2021 - Гучинова Э.-Б. Как калмыки рассказывают о депортации: дискурсивные стратегии нарратива // Сибирские исторические исследования. 2021. № 2. C. $30-52$.

Дробязко 2004 - Дробязко С. И. Под знаменами врага. Антисоветские формирования в составе германских вооруженных сил 1941-1945 гг. М.: Эксмо, 2004. 608 с.

Зберовская 2010 - Зберовская Е. Л. Спецпоселенцы в Сибири (1940-1950-е гг.). Красноярск: Изд-во Красноярского гос. аграрного ун-та, 2010. 179 с.

Земсков 1990 - Земсков В. Н. Спецпоселенцы (по документам НКВД-МВД СССР) // Социологические исследования. 1990. № 11. С. 3-17.

Земсков 1991а - Земсков В. Н. Заключенные, спецпоселенцы, ссыльнопоселенцы, ссыльные и высланные (Статистико-географический аспект) // История СССР. 1991. № 5. С. 151-165.

Земсков 19916 - Земсков В. Н. Массовое освобождение спецпереселенцев и ссыльных (1954-1960 гг.) // Социологические исследования. 1991. № 1. С. 5-26.

Земсков 2005 - Земсков В. Н. Спецпоселенцы в СССР: 1930-1960: дисс. ... д-ра ист. наук. М., 2005. 415 c.

Иванов 2013 - Иванов А. С. Депортированные калмыки на территории Омской и Тюменской областей 1943-1959 гг.: дисс. ... канд. ист. наук. Сургут, 2013. 269 с.

Иванов 2014 - Иванов А. С. «Изъять, как антисоветский элемент...»: калмыки в государственной политике (1943-1959 гг.). М.: ИРИ РАН, 2014. 294 с.

Максимов 2010 - Максимов К. Н. Великая Отечественная война: Калмыкия и калмыки. М.: Наука, 2010. 406 с. 


\section{Монголоведение • Mongolian Studies • 2021 • T. 13 • № 4}

Максимов 2013 - Максимов К. Н. Калмыкия в советскую эпоху: политика и реалии. Элиста: Герел, 2013. 464 с.

Очерки истории 1970 - Очерки истории Калмыцкой АССР. Т. 2. Эпоха социализма. М.: Наука, 1970. 432 c.

Очиров 2019 - Очиров У. Б. Жители Калмыкии - военнослужащие Красной армии, представленные, но не награжденные «Золотой Звездой» // Magna adsurgit: historia studiorum. 2019. № 2. C. 174-188.

Очиров, Воробьева 2020 - Очиров У. Б., Воробьева В. Н. Калмыки-военнослужащие Красной армии в Широклаге: статистическое исследование // Oriental Studies. 2020. T. 13. № 2. C. 330-357. DOI: 10.22162/2619-0990-2021-48-2-330-357

Полян 2001 - Полян П. М. Не по своей воле... История и география принудительных миграций в СССР. М.: ОГИ, 2001. 315 с.

Серазетдинов, Иванов 2007 - Серазетдинов Б. У., Иванов А. С. История повседневной жизни калмыков на Югорской земле в военное лихолетье 1941-1945 гг. Сургут: Изд-во СурГУ, 2007. 208 с.

Убушаев 1991 - Убушаев В. Б. Калмыки: выселение и возвращение. Элиста: Санан, $1991.96 \mathrm{c}$.

Убушаев 2007 - Убушаев В. Б., Убушаев К. В. Калмыки: выселение, возвращение, возрождение. 1943-1957 гг. Элиста: КалмГУ, 2007. 496 с.

\section{References}

Bugay N. F. Beria to Stalin: 'After Receipt of Your Directives the Following Measures Were Undertaken ...'. Moscow: Grif \& Co., 2011. 507 p. (In Russ.)

Bugay N. F. Beria to Stalin: 'In Accordance with Your Directive ...'. Moscow: AIRO-XX, 1995.320 p. (In Russ.)

Bugay N. F. Beria to Stalin: 'Loaded onto freight trains and sent to destined areas'. Istoriya SSSR. 1991. No. 1. Pp. 143-165. (In Russ.)

Bugay N. F. Operation Ulusy. Elista, 1991. 88 p. (In Russ.)

Bugay N. F. Revisiting 1930s-1940s deportations of Soviet peoples. Istoriya SSSR. 1989. No. 6. Pp. 135-144. (In Russ.)

Bugay N. F. The 1920s-1940s: Deportations from European Russia. Otechestvennaya istoriya. 1992. No. 4. Pp. 37-49. (In Russ.)

Bugay N. F. The 1940s-1950s: Consequences of ethnic deportations (Accounts from the NKVD-MVD of the USSR). Otechestvennaya istoriya. 1992. No. 1. Pp. 122-143. (In Russ.)

Chugaev D. A. (ed.) Kalmyk ASSR: Historical Essays. Vol. 2: Socialist Era. Moscow: Nauka, 1970. 432 p. (In Russ.)

Drobyazko S. I. Under Banners of the Enemy: Anti-Soviet Units of Nazi Germany's Military, 1941-1945. Moscow: Eksmo, 2004. 608 p. (In Russ.)

Godaev P. O., Shurungov A. B. Operation Parashyutisty. In: In the Name of Russia’s Security. Elista: Federal Security Service (Kalmykia Dept.), 2005. Pp. 159-170. (In Russ.)

Guchinova E.-B. 'Everyone has one's own Siberia': Two stories of the Kalmyk Deportation (Interviews with S. M. Ivanov and S. E. Naranova). Oriental Studies. 2019. Vol. 12. No. 3. Pp. 397-422. (In Russ.) DOI: 10.22162/2619-0990-2019-43-3-397-422

Guchinova E.-B. 'Everyone has one's own Siberia': Years of war and deportation in monologues of Lidzhi T. Dordzhiev and Elizaveta S. Basanova. Oriental Studies. 2020. Vol. 13. No. 4. Pp. 976-1011. (In Russ.) DOI: 10.22162/2619-0990-2020-50-4-976-1011

Guchinova E.-B. 'I was deported, you lost your leg': Kalmyk Deportation of 1943-1956 in a gender perspective. Acta Slavica Iaponica. 2007. Vol. 24. Pp. 74-99. (In Russ.)

Guchinova E.-B. Everyone has one's own Siberia: Two stories of Kalmyk Deportation. Forum for Anthropology and Culture. 2005. No. 3. Pp. 400-444. (In Russ.) 


\section{Источниковедение}

Guchinova E.-B. How Kalmyks talk about deportation: Discursive narrative strategies. Siberian Historical Research. 2021. No. 2. Pp. 30-52. (In Russ.)

Guchinova E.-B. Kalmuk Road: History, Culture, and Identity in U.S. Kalmyk Community. St. Petersburg: Aletheia, 2004. 328 p. (In Russ.)

Guchinova E.-B. To Be Remembered Not Forgotten: Anthropology of Kalmyk Deportation Trauma. Stuttgart: Ibidem, 2005. 283 p. (In Russ.)

Ivanov A. S. 'To Be Expelled as Ant-Soviet Elements ...': Kalmyks in State Policies, 19431959. Moscow: Institute of Russian History (RAS), 2014. 294 p. (In Russ.)

Ivanov A. S. Deported Kalmyks in Omsk and Tyumen Oblasts, 1943-1959. Cand. Sc. (history) thesis. Surgut, 2013. 269 p. (In Russ.)

Maksimov K. N. Kalmykia in the Soviet Era: Policy and Realia. Elista: Gerel, 2013. 464 p. (In Russ.)

Maksimov K. N. The Great Patriotic War: Kalmykia and Kalmyks. Moscow: Nauka, 2010. 406 p. (In Russ.)

Ochirov U. B. Singled out never to be awarded: Kalmyk Red Army servicemen and the title Hero of the Soviet Union. Magna adsurgit: historia studiorum. 2019. No. 2. Pp. 174-188. (In Russ.)

Ochirov U. B., Vorobyova V. N. Kalmyk Red Army soldiers in Shirokovsky Forced Labor Camp: A statistical survey. Oriental Studies. 2020. Vol. 13. No. 2. Pp. 330-357. (In Russ.) DOI: 10.22162/2619-0990-2021-48-2-330-357

Polyan P. M. 'Unwillingly...': History and Geography of Forced Migrations in the USSR. Moscow: OGI, 2001.315 p. (In Russ.)

Serazetdinov B. U., Ivanov A. S. Kalmyks in Yugra Land during the Harsh War Years, 19411945: A History of Household Life. Surgut: Surgut State University, 2007. 208 p. (In Russ.)

Ubushaev V. B. The Kalmyks: Deportation and Return. Elista: Sanan, 1991. 96 p. (In Russ.)

Ubushaev V. B., Ubushaev K. V. The Kalmyks: Deportation, Return, 1943-1957. Elista: Kalmyk State University, 2007. 496 p. (In Russ.)

Zberovskaya E. L. Forced Settlers in Siberia, 1940s-1950s. Krasnoyarsk: Krasnoyarsk State Agrarian University, 2010. 179 p. (In Russ.)

Zemskov V. N. Forced Settlers in the USSR, 1930s-1960s. Dr. Sc. (history) thesis. Moscow, 2005. 415 p. (In Russ.)

Zemskov V. N. Forced settlers: A case study of documents from the NKVD-MVD of the USSR. Sotsiologicheskie issledovaniya (Sociological Studies). 1990. No. 11. Pp. 3-17. (In Russ.)

Zemskov V. N. Mass liberation of forced settlers and repressed individuals, 1954-1960. Sotsiologicheskie issledovaniya (Sociological Studies). 1991. No. 1. Pp. 5-26. (In Russ.)

Zemskov V. N. Prisoners, forced and relocated settlers, the repressed deported: A statisticaland-geographical aspect. Istoriya SSSR. 1991. No. 5. Pp. 151-165. (In Russ.) 